\section{Oxadiazon, Oryzalin, and Oxyfluorfen Residues in Container Plant Nurseries}

\author{
P.B. Goodwin ${ }^{\mathbf{1}}$ and S. Beach \\ Horticultural Science, Department of Crop Sciences, University of Sydney, \\ New South Wales 2006, Australia
}

Additional index words. herbicide, runoff, recycled water, substrate, Lavandula pedunculata, Buxus microphylla

\begin{abstract}
Ronstar $^{\circledR}$ and Rout ${ }^{\circledR}$ are two of the most common and effective preemergent herbicides used by the nursery industry. However, there is some uncertainty as to what happens to the chemicals in nurseries that are recycling their runoff water. The fate of the chemicals has been studied in two nurseries that are completely dependent on recycled water. Negligible amounts were found in the recycled irrigation water. Most of each herbicide remained where it was applied, either close to the top in the substrate, or on the surface of the growing area, for periods of $\approx 4$ months. Five months after application, $<10 \%$ of oryzalin remained vs. $\approx \mathbf{3 0} \%$ of the oxyfluorfen and oxadiazon. Less residue was produced if oxadiazon was applied when the pots were packed together after potting up, compared to application to spaced pots in the standing area. These herbicides are of low mammalian toxicity, and the main hazard is from contamination on the standing area after application, and from the top layer of substrate. To minimize any risk, we recommend that the herbicides be applied before the plants are spaced out on the growing area, and that staff handling the pots take suitable precautions, and in particular avoid inserting their unprotected hands into the top of the mix. Chemical names used: 2-tert-butyl-4-(2,4dichloro-5-isopropoxyphenyl)- $\Delta^{2}-1,3,4-0 x a d i a z o l i n-5-o n e(o x a d i a z o n)$; 4-(dipropylamino)3,5,-dinitrobenzenesulfonamide (oryzalin); 2-chloro-1-(3-ethoxy-4-nitrophenoxy)-4(trichloromethyl)benzene (oxyfluorfen); tritium-labelled [ $N$-(4-chloro-2-fluoro-S(propargyloxy)-phenyl]-3,4,5,6-tetrahydrophthalimide $\left[{ }^{3} \mathrm{H}\right] \mathrm{THP}$.
\end{abstract}

Oxadiazon (Ronstar ${ }^{\circledR}$; Rhone-Poulenc Rural Australia, Sydney, Australia) and oryzalin plus oxyfluorfen (Rout ${ }^{\circledR}$; Grace-Sierra Australia, Sydney, Australia) are very widely used in the nursery industry for preemergence weed control (e.g., Gilliam et al., 1990). They control a wide range of weeds, and have damaging effects on few established plants. However, in cold weather they can be phytotoxic, especially with repeated applications, if they are present in the irrigation water (when it is applied to the foliage with watering), and if the water is unevenly applied (Bhandary et al., 1997; Glaze et al., 1987). Certain plants are more sensitive to oxadiazon, including Proteaceae (Sharman, 1993), daylily (Hemerocallis sp. 'Aztec Gold') (Norcini and Aldrich, 1992), and ivy (Ilex $\times$ attenuata and Ilex crenata Thunb) (Thetford and Gilliam, 1991). However, numerous reports, e.g., Derr (1994) and Jusaitis (1993), indicate that it causes less damage than other herbicides studied. Species from the families Poaceae and Proteaceae ap-

Received for publication 2 July 2000. Accepted for publication 31 Oct. 2000. This research was partially funded by the Horticultural Stock and Nurseries Act of New South Wales, Australia, and the Horticultural Research and Development Corp., Australia, under grant NY 95025. The cost of publishing this paper was defrayed in part by the payment of page charges. Under postal regulations, this paper therefore must be hereby marked advertisement solely to indicate this fact.

${ }^{1}$ To whom reprint requests should be addressed. E-mail address: GoodwinP@agric.usyd.edu.au pear to be sensitive to the combination of oryzalin and oxyfluorfen, and to other oryzalincontaining herbicides (Green et al., 1997; Jusaites, 1993; Neal and Senesac, 1991). It can also reduce rooting of cuttings during propagation (Gilliam et al., 1993).

The fate of applied oxadiazon has been studied to only a limited extent. It is used for weed control in rice (Oryza sativa L.), and has been shown to be poorly soluble in water $(0.7$ $\left.\mathrm{mg} \cdot \mathrm{L}^{-1}\right)$, strongly bound by soil organic matter, and subject to little direct leaching (Barrett and Lavy, 1984). Wehtje et al. (1993) applied $\mathrm{C}^{14}$-ring labelled oxadiazon to container plants leached after five washings with water. They concluded that the herbicide is unlikely to enter the soil or water environment. However, in a nursery situation, $20 \%$ to $80 \%$ of herbicide applied falls between pots when it is applied to spaced pots (Gilliam et al., 1992). Herbicides can leach from sandy soils (Fourie, 1993) and be washed away with storm water. Indeed oxadiazon has been found in the environment, in water and in fish, in shellfish, and in sediments (Crane and Younghans-Haug, 1992; Murakami et al., 1992; Tsuda et al., 1991), and even in some tap water in Japan (Tsumura et al., 1994).

Only low levels of oryzalin or oxyfluorfen have been detected in irrigation or sediment from nurseries using Rout ${ }^{\circledR}$ and recycled water (Camper et al., 1994). Most residues were found in the runoff water within the first 15 min. of runoff, with oryzalin being the most rapidly released component (Keese et al., and found that only $5.4 \%$ of the chemical had
1994). Oxyfluorfen is strongly bound to the organic components of potting mix (Horowitz and Elmore, 1991) and is relatively immobile in soil.

Toxicological studies indicate that there could be some concern if these chemicals are released into the environment. Oxadiazon is a suspected oncogen (Mattern et al., 1991), and is moderately to slightly acutely toxic, causing hepatic porphyria (Von Burg, 1994). Its metabolites are the phenol, methoxy acid, and alcohol derivatives (Murakami et al., 1992) and caused an increase in thyroid, mammary, and skin tumours when fed at $135 \mathrm{mg} \cdot \mathrm{kg}^{-1}$ for 2 years, and large doses led to adverse changes in blood formation in dogs (Ahrens, 1994). Oxyflurofen inhibits chlorophyll biosynthesis and promotes the oxidation of lipids and proteins in plants, leading to loss of membrane integrity (Ahrens, 1994). In animals, oxyfluorfen affects erythrocytes through the heme biosynthesis pathway, leading to $\approx 50 \%$ decrease in $\left[{ }^{3} \mathrm{H}\right] \mathrm{THP}$ binding in mouse liver mitochondria, after feeding only $4 \mathrm{mg} \cdot \mathrm{kg}^{-1}$ of body weight. The $\left[{ }^{3} \mathrm{H}\right] \mathrm{THP}$ was developed as a radioligand probe for protox, protoporphyrinogen oxidase, the inhibitor/herbicide-binding site in mouse liver mitochondria (Birchfield and Casida, 1996).

The objective of this work was to determine the concentration and location of oxadiazon, oryzalin, and oxyfluorfen residues, and the changes with time after application in nurseries that were recycling runoff water.

\section{Materials and Methods}

The trials were carried out on two nurseries located $45 \mathrm{~km}$ northwest of Sydney, Australia (lat. $33^{\circ} 37^{\prime} \mathrm{S}$, long. $151^{\circ} 04^{\prime} \mathrm{E}$ ). Both are completely dependent on rain and recycled water, with runoff collected in dams at the nursery, and no runoff beyond the nurseries except in the most exceptional circumstances.

Plants. Both nurseries were growing a wide range of species, all treated with granular preemergent herbicide at the time of planting out in the autumn. The nursery where the oxadiazon study was carried out grows a range of herbaceous perennials. The studies reported here were on a block planted with lavender (Lavandula pedunculata 'Purple Crown') in 140-mm (1.4-L) pots. The substrate was a proprietary mix from Debco, Tyabb, Australia, containing pinebark plus copra peat, with the addition of $25 \%$ perlite and $1 \mathrm{~kg} \cdot \mathrm{m}^{-3}$ of Green Jacket slow release fertilizer (Debco, Tyabb, Australia). The studies on oryzalin plus oxyfluorfen were at a nursery growing a range of trees and shrubs in 140-mm (1.4-L) pots with a substrate of medium-coarse and fine pine bark and 10\% sand, containing 4 $\mathrm{kg} \cdot \mathrm{m}^{-3}$ Green Jacket slow-release fertilizer. The trials were on a block planted to Buxus microphylla 'Japonica'.

At both nurseries, the plants were overhead-irrigated and stood on a growing area of subsoil, covered by a layer of gravel $\approx 10 \mathrm{~cm}$ deep, which was covered in turn by a layer of weed mat. The plant pots were spaced out on the weed mat $\approx 70 \mathrm{~mm}$ apart. 
Application of oryzalin plus oxyfluorfen. No preemergent herbicide was applied between Aug. 1997 and 27 Mar. 1998. On 28 Mar. and 16 Nov. 1998, $10 \mathrm{~g} \cdot \mathrm{m}^{-2}$ of Rout ${ }^{\circledR}$ ( $0.2 \mathrm{~g}$ oxyfluorfen plus $0.1 \mathrm{~g}$ oryzalin) was applied. Samples were taken for analysis on 21 Apr., 20 May, 23 June, 21 Aug., 25 Sept., and 3 Dec. 1998 (24, 53, 87, 147, and $181 \mathrm{~d}$ after the first application and $17 \mathrm{~d}$ after the second application). Samples were taken of the irrigation, dam, and runoff collection basin water or silt.

Effect of application method on oxadiazon levels. No oxadiazon was applied to the experimental site between 11 July 1996 and 16 Apr. 1997. Samples were taken on 24 Oct. 1996 and 8 Apr. 1997 to establish the background concentrations. Two methods of application were used. First, oxadiazon was applied to the pots once plants had been potted up, set out in the growing area, and watered in. This is the normal method used at the nursery. This was compared with applying the herbicide to the pots as soon as they had been potted up, on trolleys, before being moved to the growing area and set out and watered in. In both cases, the rate of application of $\operatorname{Ronstar}^{\circledR}$ was $20 \mathrm{~g} \cdot \mathrm{m}^{-2}$ (0.4 g oxadiazon).

The normal cycle of production in the nursery where the oxadiazon trial was conducted is propagation in the late summer (January and February), and potting up in March/ April, with most sales in the spring (September/October). The starting date for the trial was 16 Apr. 1997. Samples were taken the day after treatment and then every 6 weeks until the plants were sold in late September.

Temperature, rainfall and evaporation. Data are given in Table 1. Irrigation at both nurseries was by overhead sprinklers, $5-6 \mathrm{~mm}$ given twice per day, but varied at the manager's discretion. Rainfall and mean daily minimum temperatures over the months April to September were relatively low in 1997 , and relatively high in 1998.

Sampling. At both nurseries, sampling procedures were as follows. 1) Samples of surface water (dam) and free-run irrigation water were taken, collected from three or four positions, and mixed to give a final volume of 1 L. 2) The substrate from two to four pots, chosen at random, was well mixed, and a 100-g subsample taken. In some pots, the substrate from each pot was split into the top third, the middle third, and the bottom third before sampling, with the large plant roots from the top third taken as a separate sample. 3) The runoff collection basin collected the water and runoff from the full block of plants, $\approx 2000$ pots. The sample consisted of the mud in the collection basin in the oxadiazon trial, and of the water in the collection basin in the oryzalin plus oxyfluorfen trial. 4) Samples of $\approx 100 \mathrm{~g}$ were taken from several areas of the weed mat to give a total sampling area of $\approx 1 \mathrm{~m}^{2}$. The main component of these samples was substrate fines washed out of the pots. 5) The samples taken from beneath the weed mat were a mixture from two to four locations, and contained a mixture of silt (from earthworm activity) and gravel.

Table 1. Climatic data in 1997 and 1998 from Peats Ridge weather station, lat. $33^{\circ} 18^{\prime} \mathrm{S}$, long. $151^{\circ} 14^{\prime} \mathrm{E}$, except for rainfall, which is from Glenorie rainfall station, lat. $33^{\circ} 36^{\prime} \mathrm{S}$, long. $151^{\circ} 04^{\prime} \mathrm{E}$.

\begin{tabular}{|c|c|c|c|c|}
\hline \multirow[b]{2}{*}{ Month } & \multicolumn{2}{|c|}{ Mean daily: } & \multirow[b]{2}{*}{ Evaporation (mm) } & \multirow[b]{2}{*}{ Rainfall (mm) } \\
\hline & Maximum $\left({ }^{\circ} \mathrm{C}\right)$ & Minimum $\left({ }^{\circ} \mathrm{C}\right)$ & & \\
\hline \multicolumn{5}{|c|}{1997} \\
\hline April. & 24.1 & 11.1 & 82.4 & 5.0 \\
\hline May & 18.9 & 10.3 & 56.6 & 51.0 \\
\hline June & 16.7 & 6.6 & 44.8 & 52.4 \\
\hline July & 15.2 & 5.1 & 43.4 & 77.2 \\
\hline August & 17.9 & 4.7 & 77.2 & 2.8 \\
\hline September & 18.9 & 8.5 & 78.4 & 90.6 \\
\hline \multicolumn{5}{|c|}{1998} \\
\hline March & 27.5 & 15.8 & 126.2 & 8.8 \\
\hline April & 22.8 & 12.3 & 88.6 & 108.4 \\
\hline May & 18.6 & 10.2 & 55.4 & 313.2 \\
\hline June & 16.0 & 8.1 & 47.8 & 89.6 \\
\hline July & 14.6 & 6.3 & 50.4 & 73.7 \\
\hline August & 16.8 & 7.7 & 57.8 & 255.8 \\
\hline September & 20.6 & 10.1 & 87.8 & 45.4 \\
\hline October & 22.8 & 10.4 & 121.6 & 39.8 \\
\hline November & 21.2 & 11.6 & 99.0 & 85.6 \\
\hline
\end{tabular}

Analyses for presence and concentration of the three chemicals were carried out by Australian Government Analytical Laboratories (AGAL) at Pymble, NSW, Australia. For the analysis of oryzalin and/or oxyfluorfen, the water samples were processed by liquidliquid extraction, and the soil and substrate samples were processed by solid-liquid extraction.

The liquid-liquid extraction method used $400 \mathrm{~mL}$ of sample in a 1-L separatory funnel. The $\mathrm{pH}$ was adjusted to 11 using sodium hydroxide and the aqueous phase extracted with $50 \mathrm{~mL}$ of dichloromethane (DCM); the bottom layer (DCM) was transferred into a TurboVap tube (Zymark Corp., Hopkinton, Ma.). The previous step was repeated before the DCM in the TurboVap tube was concentrated down and the solvent exchanged to a final volume in acetone using a Zymark TurboVap2 Concentration Workstation. The concentrated extract was then analysed on a Hewlett Packard 5890 gas chromatograph (Hewlett Packard, Little Falls, Del.) using an electron capture detector (ECD). The presence of oryzalin and/or oxyfluorfen were first detected on a J\&W $30 \mathrm{~m} \mathrm{DB}-17$ column (J\&W Scientific, Folsom, Calif.) and then reconfirmed on a J\&W 30 m DB-1 column.

The solid-liquid extraction consisted of weighing out a 10-g sample into a jar. About 1 $\mathrm{g}$ of anhydrous, granular, sodium carbonate was added to adjust the $\mathrm{pH}$ to 11 . Fifty milliliters of 3 hexane : 2 acetone (v/v) was added, mixed vigorously for $2 \mathrm{~h}$, and then allowed to stand. The acetone/hexane layer was then passed through a column of anhydrous sodium sulfate to remove any remaining water. The extract was then analysed using the same gas chromatograph described above.

For the analysis of oxadiazon, $10-\mathrm{g}$ soil and substrate samples were extracted with $50 \mathrm{~mL}$ of 2 hexane: 1 acetone $(\mathrm{v} / \mathrm{v})$. The extract was run directly on a dual column (DB1701 and DB5) gas chromatograph with dual ECD. Water samples (200-300 mL) were extracted with dichloromethane, which was concentrated to a volume $1 \%$ of the original sample size (e.g., $200 \mathrm{~mL}$ sample to $2 \mathrm{~mL}$ ), then analyzed using the same gas chromatograph conditions as for soils. This is the AGAL in-house method, which is based on U.S. Environmental Protection Agency methods. Recovery rates (means $\pm 95 \%$ confidence intervals) for water were $94 \% \pm 37 \%$, for substrate $119 \% \pm 43 \%$, and for soil $110 \% \pm 19 \%$. Detection limits for oxyfluorfen and oxadiazon were $0.1 \mathrm{mg} \cdot \mathrm{kg}^{-1}$ in soil and substrate, and $0.1 \mu \mathrm{g} \cdot \mathrm{L}^{-1}$ in water. Detection limits for oryzalin were $1.0 \mathrm{mg} \cdot \mathrm{kg}^{-1}$ in soil and substrate, and $1.0 \mu \mathrm{g} \cdot \mathrm{L}^{-1}$ in water.

\section{Results}

Oryzalin plus oxyfluorfen. Although the initial runoff water from pots after application of Rout ${ }^{\circledR}$ contained $43 \mathrm{mg} \cdot \mathrm{L}^{-1}$ oryzalin and 4.9 $\mathrm{mg} \cdot \mathrm{L}^{-1}$ oxyfluorfen, levels measured in the runoff collection basin water were always below $1 \mu \mathrm{g} \cdot \mathrm{L}^{-1}$ for both herbicides, except for a value of $1.4 \mu \mathrm{g} \cdot \mathrm{L}^{-1}$ oryzalin on $21 \mathrm{Apr}$. (Table 2). Levels in dam water, irrigation water and the dam silt were always below the detectable limit.

Relatively high concentrations of residues were found on the weed mat (Fig. 1), peaking at $130 \mathrm{mg} \cdot \mathrm{kg}^{-1}$ oxyfluorfen on 3 Dec., $17 \mathrm{~d}$ after the application on 16 Nov., and, in general, declining with time during the 5 months after the first application. Only very low (oxyfluorfen on $3 \mathrm{Dec}$.) or nondetectable amounts were found below the weed mat.

The other location of much of the oryzalin and oxyfluorfen was in the substrate in which the plants were growing (Table 3). Oryzalin was found only in the top third of the mixture. Concentrations declined with time until reapplication in mid-November. Oxyfluorfen was more persistent in the substrate. As with oryzalin, the highest concentration was found in the mix near the top of the pot, but appreciable herbicide was also found in the middle and bottom of the pot. Concentrations declined with time, but to a far smaller extent than those of oryzalin, with about a third still present 5 months after application compared to $<10 \%$ of the oryzalin. 
Oxadiazon trial. The background levels of oxadiazon found before the experiment started are given in Table 4 . Even 9 months after the last application, the chemical was still present in trace amounts in the irrigation water, and in the soil below the weedmat. Thus, oxadiazon is a persistent chemical in the nursery environment.

On the day after application, the amount of oxadiazon in the standing area following application on the trailers was $\approx 1 \%$ of that following application to the spaced-out plants (Table 5). Treating the plants before placement on the growing area greatly reduced the amount of chemical likely to reach the irrigation water. For example, the runoff collection basin below the site also had $<1 \%$ of the amount of chemical found with on-site application. Even 5 months later, the latter collection basin had only $10 \%$ of the concentration of the on-site treatment. The effect of the two application methods on the levels in recycled water could not be determined, but this also should be far less with application before spacing out.

The highest oxadiazon concentration was found on the surface of the weed mat following application to spaced-out pots. The concentration of oxadiazon on the weed mat fell with time following treatment on the growing area. There were no clear trends with time at the other locations, or in the other treatment, except perhaps for an increase in concentration in the run-off collection basin below the block where the pots were treated on the trailer.

The data in Table 5 indicates the average concentration of oxadiazon in the pot. However, most of the chemical is in the top third of the substrate (Table 6). Note the higher concentration at the bottom of pots treated on the standing area. This will have entered the bottom of the pot by capillary uptake. The results indicate the immobility and stability of the compound.

\section{Discussion}

In agreement with data from previous studies (Barrett and Lavy, 1984; Keese et al., 1994), oryzalin was rapidly released from the pots, whereas both oxyfluorfen and oxadiazon were more strongly retained. To appreciate the significance of the concentrations of the residues, they must be compared with concentrations shown to be hazardous (Table 7).

Toxic levels for plants. In the irrigation water: Glaze et al. (1987) found damage to aucuba (Aucuba japonica Thunb.), azalea [(Rhododendron (AZ)], liriope [Liriope muscari (Decne) L.H. Bailey], pampas grass [Cortaderia selloana (Schult. \& Schult. f.) Asch. \& Graebn.], Japanese black pine (Pinus thunbergiana Franco), and red tip photinia (Photinia 'Fraseri' Dress) plants from oxadiazon applied in a liquid formulation at rates of $8.8 \mathrm{mg} \cdot \mathrm{L}^{-1}$ and above. We found 0.16 $\mu \mathrm{g} \cdot \mathrm{L}^{-1}$ in the irrigation water, which is over four orders of magnitude less than the toxic level for the sensitive plants used by Glaze and coworkers. The results for oryzalin and
Table 2. Oryzalin and oxyfluorfen residue concentrations $\left(\mu \mathrm{g} \cdot \mathrm{L}^{-1}\right)$ in runoff water following application of Rout ${ }^{\circledR}$ on 28 Mar. and 16 Nov. 1998

\begin{tabular}{lccc}
\hline \hline Source & Date & Oryzalin & Oxyfluorfen \\
\hline Initial runoff from pots & 28 Mar. & 43 & 4.9 \\
Runoff collection basin & 21 Apr. & 1.4 & 0.95 \\
& 20 May & $<1$ & 0.18 \\
& 23 June & $<1$ & 0.17 \\
& 21 Aug. & $<1$ & 0.16 \\
& 25 Sept. & $<1$ & $<0.1$ \\
& 3 Dec. & $<1$ & 0.13 \\
\hline
\end{tabular}

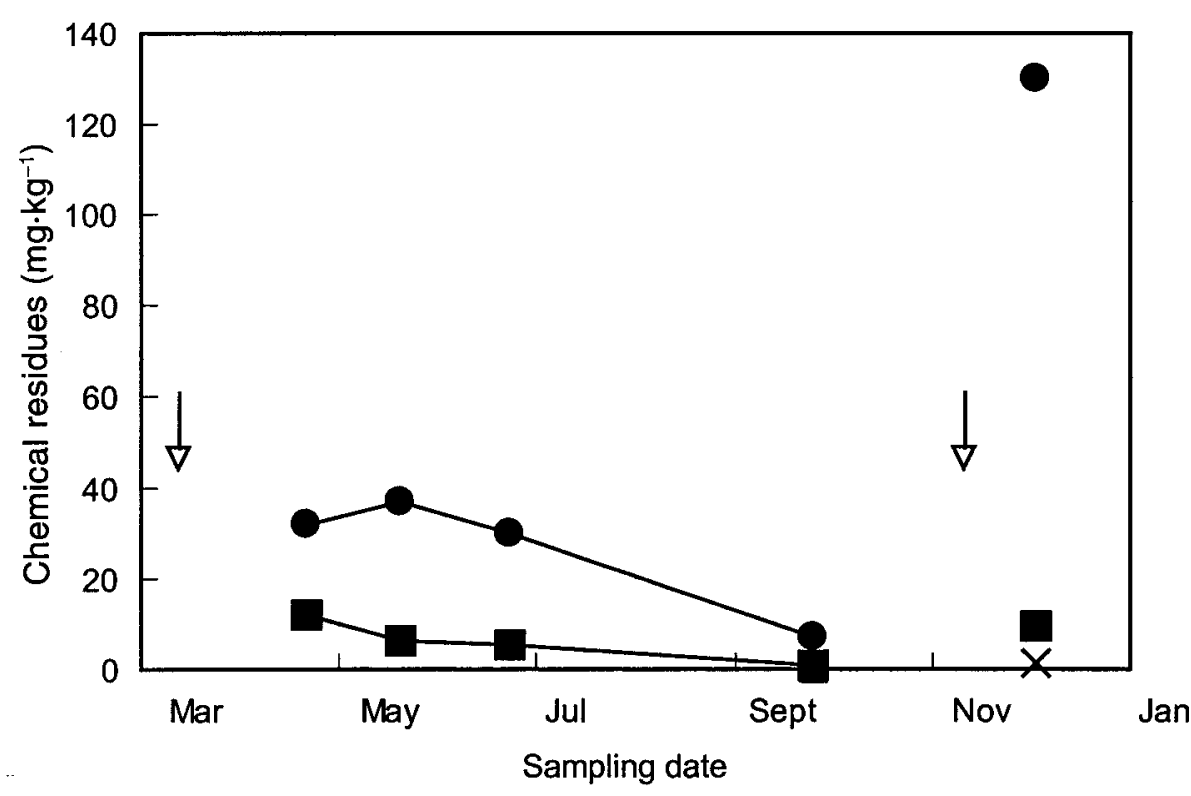

Fig. 1. Residues of oryzalin and oxyfluorfen in the area used for growing container plants. vertical arrows indicate times of Rout ${ }^{\circledR}$ application. $\mathbf{Q}=$ oxyfluorfen on the weed mat; $\mathbf{\square}=$ oryzalin on the weed mat; $X=$ oxyfluorfen under the weed mat. Under the weed mat, there was no detectable oxyfluorfen at earlier sampling dates, and no detectable oryzalin.

Table 3. Oryzalin and oxyfluorfen residues $\left(\mathrm{mg} \cdot \mathrm{kg}^{-1}\right)$ in samples from the top third, the middle third, and the bottom third of the pot plant substrate. Rout ${ }^{\circledR}$ was applied on 28 Mar. and 16 Nov. 1998.

\begin{tabular}{|c|c|c|c|c|c|}
\hline \multirow[b]{3}{*}{ Date } & \multirow{3}{*}{$\begin{array}{l}\text { Time after } \\
\text { application }(\mathrm{d})\end{array}$} & \multicolumn{4}{|c|}{ Position in pot } \\
\hline & & \multirow{2}{*}{$\begin{array}{c}\text { Top } \\
\text { Oryzalin }^{z}\end{array}$} & Top & Middle & Bottom \\
\hline & & & \multicolumn{3}{|c|}{ Oxyfluorfen } \\
\hline 21 Apr. & 24 & $<1$ & 7.2 & $x^{y}$ & $x$ \\
\hline 20 May & 53 & 3.5 & 4 & 0.34 & 0.18 \\
\hline 23 June & 87 & 1 & 3.9 & 0.18 & 0.44 \\
\hline 25 Sept. & 181 & 0.27 & 2.38 & 0.22 & 0.3 \\
\hline 3 Dec. & 17 & 3 & 19 & 2.7 & 2.8 \\
\hline
\end{tabular}

${ }^{2}$ Oryzalin residues were not detectable in samples from the middle or bottom thirds of the pots.

${ }^{y_{X}}=$ not measured.

Table 4. Background oxadiazon levels $\left(\mu \mathrm{g} \cdot \mathrm{L}^{-1}\right)$ for water, otherwise $\mathrm{mg} \cdot \mathrm{kg}^{-1}$ ) 1996-97.

\begin{tabular}{lcc}
\hline \hline Source of sample & 24 Oct. $^{\mathrm{z}}$ & 8 Apr. \\
\hline Dam water & $<1$ & $\mathrm{X}^{\mathrm{x}}$ \\
Irrigation water & $<1$ & 0.15 \\
Pot plant ready for sale & 6.2 & $\times^{\mathrm{x}}$ \\
Substrate fines, etc. on weedmat & 69 & 1.8 \\
Soil immediately under weedmat & 3 & 3.2 \\
Mud from runoff trap below standing area & 4 & $<0.1$ \\
Silt above the dam & 0.9 & $\times^{\mathrm{x}}$ \\
Silt in dam & 0.4 & $\times^{\mathrm{x}}$ \\
\hline
\end{tabular}

${ }^{2} 3$ months after last application.

y9 months after last application.

${ }^{\mathrm{x}} \mathrm{X}=$ not measured. 
oxyfluorfen were similar, with damage to sensitive species at $1 \mathrm{mg} \cdot \mathrm{L}^{-1}$ (Ahrens, 1994); concentrations in the irrigation water were always below the detection limits of $1 \mu \mathrm{g} \cdot \mathrm{L}^{-1}$ (oryzalin) or $0.1 \mu \mathrm{g} \cdot \mathrm{L}^{-1}$ (oxyfluorfen), which is $<0.1 \%$ of the toxic level. Thus, our results indicate that the risk to the nursery plants from recycled pre-emergent herbicide in the irrigation water is essentially zero. This is in agreement with the studies of Camper et al. (1994) on oryzalin and oxyfluorfen conducted in South Carolina.

The main hazard to established plants is directly from the applied herbicide; however there is an extensive literature on what species are sensitive. Note that that the herbicides are still present at an effective concentration in the upper layers of the substrate when the plants are sold, so that for a limited time they could continue acting as preemergent herbicides in customer's gardens.

Environmental risk. The environmental risk to wild species from the recycled water appears to be low. Toxic levels for one of the more sensitive species, rainbow trout (Oncorhynchus mykiss Walbaum) are given in Table 7. Peak concentrations found in the runoff collection basin water, which were much higher than in the dam water, were still only $0.1 \%$ of the reported $\mathrm{LC}_{50}$ levels. Nevertheless, the $\mathrm{LC}_{50}$ concentrations are lethal

Table 5. Oxadazon concentrations $\left[\mathrm{mg} \cdot \mathrm{kg}^{-1}\right.$ (soil or plant substrate) or $\mu \mathrm{g} \cdot \mathrm{L}^{-1}$ (water)] following application of $\operatorname{Ronstar}^{\circledR}$ on 16 Apr. 1997 to Lavandula pedunculata 'Purple Crown' plants in 140$\mathrm{mm}$ pots.

\begin{tabular}{lccccc}
\hline \hline & & \multicolumn{4}{c}{ Time (d after application) } \\
\cline { 3 - 6 } Site of application & Sample & 1 & 48 & 97 & 163 \\
\hline--- & Dam water & $\times^{2}$ & 0.26 & $\times^{2}$ & 0.11 \\
-- & Irrigation water & 0.11 & 0.16 & 0.08 & 0.15 \\
Trailer & Substrate on weed mat & 21.0 & 40.0 & 21.0 & 28.0 \\
& Soil under weed mat & 0.05 & 0.14 & 0.13 & 0.25 \\
& Soil in runoff collection basin & 0.013 & 0.14 & 0.09 & 0.63 \\
Growing area & Plant substrate & 31.0 & 8.7 & 26.0 & $\times^{2}$ \\
& Substrate on weed mat & 5200.0 & 3200.0 & 1500.0 & 230.0 \\
& Soil under weed mat & 3.2 & 8.8 & 5.8 & 4.2 \\
& Soil in runoff collection basin & 5.6 & 9.0 & 9.0 & 6.0 \\
& Plant substrate & 18.0 & 24.0 & 18.0 & $\times^{2}$ \\
\hline
\end{tabular}

${ }^{\mathrm{z}} \mathrm{x}=$ not measured

Table 6. Oxadiazon concentration $\left(\mathrm{mg} \cdot \mathrm{kg}^{-1}\right)$ in pot plants ready for sale. The herbicide had been applied 9 months earlier, to pots either compacted together pot-to-pot on the trailer, or spaced out on the growing area.

\begin{tabular}{lcccc}
\hline & Roots from top & \multicolumn{3}{c}{ Substrate } \\
\cline { 3 - 5 } Site of application & third of substrate & Top third & Middle third & Bottom third \\
\hline Trailer & 2.7 & 110 & 2.4 & 0.8 \\
Growing area & 3.5 & 150 & 1.6 & 16.5 \\
\hline
\end{tabular}

apart, or 210-mm center to center (pots occupy $40 \%$ of space). This will also minimize the amount of preemergent herbicide used. To minimize exposure, nursery staff should wear protective clothing, including suitable footwear and especially gloves, not only when applying the herbicide, but also when handling (i.e., spacing out, and preparing for sale) the pots.

\section{Literature Cited}

Ahrens, W.H. 1994. Herbicide handbook, $7^{\text {th }}$ Ed. Weed Sci. Soc. Amer. Champaign, Ill.

Ambrosi, D. and R. Richard. 1985. Les oxadiazoles: Une famille chimique originale de la récherche Rhone-Poulenc. La Défense des végétaux 231: 19-22.

Barrett, M.R. and T.L. Lavy. 1984. Effects of soil water content on oxadiazon dissipation. Weed Sci. 32:697-701

Bhandary, R.M., T. Whitwell, and J. Briggs. 1997. Growth of containerised landscape plants is influenced by herbicide residues in irrigation water. Weed Technol. 11:793-797.

Birchfield, N.B. and J.E. Casida. 1996. Protoporphyrinogen oxidase: High affinity tetrahydrophthalimide radioligand for the inhibitor/herbicide-binding site in mouse liver mitochondria. Chem. Res. Toxicol. 9:1135-1139

Camper, N.D., T. Whitwell, R.J. Keese, and M.B. Riley. 1994. Herbicide levels in nursery containment pond water and sediments. J. Environ. Hort. 12:8-12.

Crane, D.B. and C. Younghans-Haug. 1992. Oxadiazon residue concentrations in sediment, fish, and shellfish from a combined residential/ agricultural area in southern California. Bul. Environ. Contam. Toxicol. 48:608-615.

Derr, J.F. 1994. Weed control in container-grown herbaceous perennials. HortScience 29:95-97.

Fourie, J.C. 1993. Herbigation in a vineyard: Efficacy and persistence of five preemergence herbicides in sandy soil. South African J. Enol. and Viticult. 14:3-10.

Gilliam, C.H., D.J. Eakes, and J.W. Olive. 1993. Herbicide use during propagation affects root initiation and development. J. Environ. Hort. 11:157-159.

Gilliam, C.H., D.C. Fare, and A. Beasley. 1992. Nontarget herbicide losses from application of granular Ronstar ${ }^{\circledR}$ to container nurseries. J. Environ. Hort. 10:175-176.

Gilliam, C.H., W.J. Foster, J.L. Adrian, and R.L. Shumack. 1990. A survey of weed control costs and strategies in container production nurseries. J. Environ. Hort. 8:133-135.

Glaze, N.C., M. Singh, and S.C. Phatak. 1987. Ornamental response to two methods of oxadiazon application. HortScience 22:265-268.

Gold, L.S., B.R. Stern, T.H. Slone, J.P. Brown, N.B. Manley, and B.N. Ames. 1997. Pesticide residues in food: Investigation of disparities in cancer risk estimates. Cancer Lett. 117:195-207.

Table 7. Toxic levels of the three herbicides used.

\begin{tabular}{|c|c|c|c|c|}
\hline Species & Oryzalin & Oxyfluorfen & Oxadiazon & Source $^{2}$ \\
\hline Plants (postemergent application in irrigation water) $\left(\mathrm{mg} \cdot \mathrm{L}^{-1}\right)$ & $1^{*}$ & $1^{*}$ & $8.8^{*}$ & Bhandary et al., 1997; Glaze et al., 1987 \\
\hline —chronic toxicity $\left(\mathrm{mg} \cdot \mathrm{kg}^{-1}\right.$ body $\left.\mathrm{wt} \cdot \mathrm{d}^{-1}\right)$ & $>14$ & 2 & $20-500.0^{*}$ & Richert et al., 1996 \\
\hline Rainbow trout $96 \mathrm{~h} \mathrm{LC} \mathrm{C}_{50}\left(\mathrm{mg} \cdot \mathrm{L}^{-1}\right)$ & 3.26 & 0.4 & $1-9.0$ & \\
\hline
\end{tabular}

${ }^{\mathrm{x}}$ From Ahrens (1994) unless indicated by *. 
Green, J.C., G.K. Keever, C.H. Gilliam, C.K.Palmer, J.W. Olive, and D.J. Eakes. 1997. Effects of preemergence applied herbicides on pampas grass grown in containers. J. Environ. Hort. 15:77-80.

Horowitz, M. and C.L. Elmore. 1991. Leaching of oxyfluorfen in container media. Weed Technol. 5:175-180.

Keese, R.J., N.D. Camper, T. Whitwell, M.B. Riley, and P.C. Wilson. 1994. Herbicide runoff from ornamental container nurseries. J. Environ. Quality 23:320-324.

Jusaitis, M. 1993. Safety and efficacy of pre-emergent herbicides in container-grown Australian plants. Plant Protection Quart. 8:127-130.

Mattern, G.C., C-H. Liu, J.B. Louis, and J.D. Rosen. 1991. GC/MS and LC/MS determination of 20 pesticides for which dietary oncogenic risk has been estimated. J. Agr. Food Chem. 39:700-704.
Murakami, Y., T. Nishimune, and K. Sueki. 1992. Residue studies on oxadiazon and its metabolites in terrapin and corb shell processed foods: Studies on environmental contaminants in food. J. Food Hygenic Soc. Jpn. 33:576-585.

Neal, J.C. and A.F. Senesac. 1991. Preemergent herbicide safety in container-grown ornamental grasses. HortScience 26:157-159

Norcini, J.G. and J.H. Aldrich. 1992. Spotted spurge control and phytotoxicity to daylily from preemergence herbicides. J. Environ. Hort. 10:14-17.

Richert, L., S. Price, C. Chesne, K. Maita, and N. Carmichael. 1996. Comparison of the induction of hepatic peroxisome proliferation by the herbicide oxadiazon in vivo in rats, mice, and dogs and in vitro in rat and human hepatocytes. Toxicol. Appl. Pharmacol. 141:35-43.

Sharman, K.V.1993. Herbicides for container-grown rainforest species. HortScience 28:303-305.
Thetford, M. and C.H. Gilliam. 1991. Herbicide use in propagation: Effects on rooting and root growth of stem cuttings. J. Environ. Hort. 9:21-33.

Tsuda, T., S. Aoki, M. Kojima, and H. Harada. 1991. Pesticides in water and fish from rivers flowing intoLake Biwa. Toxicol. Environ. Chem. 34:3955.

Tsumura, Y., Y. Nakamura, Y. Tonogai, Y. Ito, Y Sobukawa, K. Shimoi, and I. Tomita. 1994. Identification and characteristics of organic compounds in tap water trapped by membrane of microporous polyethylene hollow fibres. Jpn. J. Toxicol. Environ. Health 40:244-251.

Von Burg R. 1994. Toxicology update: Oxadiazon. J. Appl. Toxicol. 14:69-71.

Wehtje, G.R., C.H. Gilliam, and B.F. Hajek. 1993. Adsorption, desorption, and leaching of oxadiazon in container media and soil. HortScience 28:126-128. 